\title{
In-vitro Callus Induction of Durian (Durio zibethinus Murr.) Leaves Using Kinetin and 2,4-D (Dichlorophenoxyacetic acid)
}

\author{
Rd. Selvy Handayani ${ }^{*}$, Ismadi Yunus ${ }^{1}$, M. Sayuti ${ }^{2}$, Endri Irawan ${ }^{2}$ \\ ${ }^{1}$ Faculty of Agriculture, Universitas Malikussaleh, 24355 \\ ${ }^{2}$ Faculty of Engineering, Universitas Malikussaleh, 24352 \\ *Corresponding email: selvy@unimalac.id
}

\section{ARTICLE HISTORY}

Received: 18 September 2019

Revised: 30 September 2019

Accepted: 15 October 2019

\section{KEYWORDS}

Auxin

Explants

Morphogenesis

Genetic resources

Cytokinin

\begin{abstract}
Durian (Durio zibethinus Murr.) is a tropical fruit grown in Southeast Asia that has high nutritional and economic values and highly appreciated by consumers in Indonesia. Unfortunately, there are several obstacles to planting durian in Indonesia, precisely in Aceh. One of the obstacles is the scarcity of superior durian plants. Generally, plant conservations are done conventionally through vegetative propagation. However, this technique has some disadvantages, one of which is that it can harm the initial plants. Therefore, plant culture tissue has been used as a modern technique to develop durian plants. The objective of this research was to evaluate the effect of kinetin and 2,4 D on the development of durian leaf explants through in-vitro bioassay. The research was conducted at Tissue Culture Laboratory, Faculty of Agriculture, Universitas Malikussaleh, from January to April 2019 using Completely Randomized Design (CRD) Factorial with two factors observed. The first factor was Kinetin (K): 0.0, 0.1 and $0.5 \mathrm{ppm}$. The second factor was auxin 2,4 D: $0.0,0.5$ and $1.0 \mathrm{ppm}$. The results showed that the in-vitro application of kinetin affected the induction of leaf callus. The application of $0.5 \mathrm{ppm}$ of kinetin gave the best result compared to others. The in-vitro application of 2,4 D $0.5 \mathrm{ppm}$ also possessed the best result compared to others. There was no interaction between the in-vitro application of kinetin and 2,4 D on the growth of durian leaf callus at all parameters observed.
\end{abstract}

This is an open access article under the CC-BY-SA license.

\section{INTRODUCTION}

Durian (Durio zibethinus Murr.) is one of the horticultural commodities which possess high nutritional and economic values. Besides, it plays an important role in the increasing national economy in Indonesia. Durian is known as The King of Fruits, originated from Southeast Asia (Feng et al., 2016). This fruit is considered as a prospective commodity not only for Indonesian people but also for export activity. Aceh is a province in Indonesia whose regions are known as production centers. Those cities are North Aceh, Pidie and Bireuen (Deptan, 2012). The production centers in North Aceh are located in Sawang, Kuta Makmur, and Langkahan.

Durian plants grown in North Aceh possess genetic diversity, which can be seen from its vegetative morphology as well as from its quality. This diversity offers uniqueness, and it has enriched the genetic diversity of Aceh durians. Durian has a unique flavor and a strong odor. Until today, studies about Aceh durians are still scanty. Limited information about this plant in Aceh is causing weak protection of local genetic resources in Aceh, which resulted in the extinction of Aceh durians or led to emblezzement of genetic resources by other parties.

One obstacle in durian cultivation in Aceh is the extinction of initial plants. Generally, the preservation is done conventionally through vegetative propagation. However, this technique may be harmful to the initial plants. To prevent the extinction of this genetic resource, modern technology is needed. One of them is through in-vitro bioassay. This method is believed to produce better seeds and identical to its parental plants (true to type) (Yunus et al., 2010).

Many factors are affecting the success of in-vitro bioassay, for example, the application of growth regulators (Sugiono dan Hasbianto, 2014) and the source of explants. There are two types of growth regulators used in in-vitro bioassays, such as cytokinin and auxin. The use of auxin together with cytokinin enables us to decide what type of morphogenesis we want to have 2,4-D (type of auxin) and kinetin (the type of cytokinin) are synthetic growth regulator which generally used in tissue culture researches. Plant researches about propagative technique 
in-vitro in plants have been done by many researchers, for instance in mangosteens (Handayani et al, 2013), orchid Phalaenopsis (Anjani, 2011), sugarcanes (Mekonnen et al., 2013) and durians (Sugiyarto dan Kuswandi, 2013; Handayani et al., 2018).

The application of a combination of growth regulators 2,4 D and kinetin to culture media can stimulate callus formation in cinnamon in various concentrations of $2,4 \mathrm{D}$ and kinetin. The application of I $\mathrm{mg} / \mathrm{L}$ of $2,4 \mathrm{D}$ and 0,1 $\mathrm{mg} / \mathrm{L}$ demonstrated the fastest formation of callus. The application of $2 \mathrm{mg} / \mathrm{L} \mathrm{2,4} \mathrm{D}$ and $1.0 \mathrm{mg} / \mathrm{L}$ possessed the highest weight of callus in cinnamon explants (Teguh, 2017). The best direct somatic embryo induction in Arabica coffee variety Kartika-1 from young leaf explants obtained from MS media treated with $4 \mathrm{mg} / \mathrm{L} \mathrm{2,4} \mathrm{D}$ combined with $0.1 \mathrm{mg} / \mathrm{L}$ kinetin (Riyadi dan Tirtoboma, 2004). The application of $0.5 \mathrm{mg} / \mathrm{L}$ of $2,4 \mathrm{D}$ and $1 \mathrm{mg} / \mathrm{L}$ of kinetin gave the best result on rodent tubers (Typhonium flagelliforme (L.) BI) (Sitinjak et al., 2015).

Different parts of plants are used as explants for micropropagation such as shoot tip, nodal and intermodal segments, shoot meristem, leaf disks, and floral parts (Yusnita, 2003; Chugh et al, 2009), seeds and micro shoots (Handayani et al., 2013). The part of the used as explants to produce callus in durian plants is the leaves. This study aimed to obtain the best sterile material for the growth of durian explant shoot in vitro.

\section{MATERIALS AND METHODS}

\subsection{Place and duration}

This research was conducted in Tissue Culture Laboratory, Faculty of Agriculture, Universitas Malikussaleh, North Aceh, from March to June 2019.

\subsection{Research methods}

The materials used in this research were young leaves obtained from durian seedbeds in North Aceh, alcohol, bleaching liquid, sugar, fungicides, bactericides, spiritus, agar, distilled water, 2,4 D, kinetin, MS media, and $\mathrm{HgCl}_{2}$. Tools used in this research were Laminar Air Flow Cabinet (LAFC), autoclave, hotplate, dan planting tools.
This research used Completely Randomized Design (CRD) factorial, with two factors and 10 replicated. The first factor was different concentrations of kinetin (0.0, 0.1 and $0.5 \mathrm{mg} / \mathrm{L}$ ) and the second factor was different concentrations of 2,4 D $(0.0,0.5$, dan $1 \mathrm{mg} / \mathrm{L})$.

Durian seeds were sown in sand seedbeds (polybags) vertically with the position of rootlets facing the ground. two-month durian seedlings were applied as explants. Durian leaf explants were washed with distilled water for 15 minutes and soaked in detergent liquid for 15 minutes, then continued with soaking each of them with fungicides/bactericides $8 \mathrm{~g} / \mathrm{L}$ for 20 minutes and then they were rewashed with distilled water. Explants then being immersed into alcohol liquid $70 \%$ for 3 minutes and washed with distilled water. Then, the explants were immersed into $\mathrm{HgCl}_{2}$ (concentration of $0.05 \%$ ) for 20 minutes and washed using distilled water and put onto sterilized papers.

Sterilized explants were cut with removing its both end tips. The middle part of leaves was cut sized $1 \times 1 \mathrm{~cm}$ and then planted into prepared growing media. Durian leaf disks were planted into growing media with the position of lower leaves facing the growing media (abaxial). The observation was done to evaluate the callus growth, growth time, percentage of developing callus and callus colour.

\section{DATA ANALYSIS}

Data obtained from this research was analyzed using the $\mathrm{F}$ test at a probability level of 5\%. Significantly different data was then analyzed using Duncan's Multiple Range Test (DMRT). The data analysis was conducted by using SAS v9.12 Software.

\section{RESULTS AND DISCUSSION}

The results showed that there was no interaction between concentrations of kinetin and $2.4 \mathrm{D}$ to all parameters observed. However, the application of kinetin and 2,4 D gave an effect on callus growth. The results of the percentage of callus are described in Table 1.

Table 1. The percentage of callus growth on durian leaf explants treated with kinetin and 2,4 D in vitro

\begin{tabular}{|c|c|c|c|c|c|}
\hline \multirow{2}{*}{ Treatments } & \multicolumn{5}{|c|}{ Callus growth (\%) } \\
\hline & 3 WAP & 4 WAP & 5 WAP & 6 WAP & 7 WAP \\
\hline \multicolumn{6}{|c|}{ Concentrations of kinetin $(\mathrm{K})$ : } \\
\hline 0 mg/L (K0) & $32(0.88 a)$ & $46(0.95 a)$ & $57(1.00 \mathrm{a})$ & $57(1.00 \mathrm{a})$ & $67(1.06 \mathrm{a})$ \\
\hline $0.1 \mathrm{mg} / \mathrm{L}(\mathrm{K} 1)$ & $11(0.74 b)$ & $14(0.78 \mathrm{~b})$ & $35(0.90 \mathrm{a})$ & $53(0.99 a)$ & $67(1.07 \mathrm{a})$ \\
\hline $0.5 \mathrm{mg} / \mathrm{L}(\mathrm{K} 2)$ & $10(0.76 \mathrm{ab})$ & $17(0.80 \mathrm{ab})$ & $32(0.88 a)$ & $53(0.99 a)$ & $57(1.01 \mathrm{a})$ \\
\hline \multicolumn{6}{|c|}{ Concentrations of 2,4-D (D) : } \\
\hline 0 mg/L (D0) & $0(0.70 \mathrm{a})$ & $0(0.70 \mathrm{~b})$ & $6(0.74 \mathrm{~b})$ & $6(0.74 c)$ & $6(0.74 \mathrm{~b})$ \\
\hline $0.5 \mathrm{mg} / \mathrm{L}$ (D1) & $20(0.82 a)$ & $44(0.94 a)$ & $61(0.03 a)$ & $82(1.14 \mathrm{a})$ & $88(1.17 \mathrm{a})$ \\
\hline $1 \mathrm{mg} / \mathrm{L}(\mathrm{D} 2)$ & $20(0.81 \mathrm{a})$ & $20(0.81 \mathrm{ab})$ & $38(0.91 \mathrm{a})$ & $50(0.97 \mathrm{~b})$ & $67(1.07 \mathrm{a})$ \\
\hline
\end{tabular}

Mean values followed by the same letters in the same columns did not differ significantly, as determined by DMRT at probability level $5 \%$. Values in parenthesis were results of transformation using formula $\sqrt[2]{(x+0,5)}, \quad$ WAP $=$ Weeks After Planting. 
Table 1 illustrates that the application of kinetin has increased the callus growth at 3 and 4 weeks after planting. The application of kinetin $0 \mathrm{mg} / \mathrm{L} \mathrm{(KO)} \mathrm{and}$ $0.1 \mathrm{mg} / \mathrm{L}$ (K1) demonstrated the highest percentage of callus growth compared to application of kinetin 0.5 $\mathrm{mg} / \mathrm{L}(\mathrm{K} 2)$.

Also, the application of $2.4 \mathrm{D}$ statistically improved callus growth. The application of 2,4 D $0.5 \mathrm{mg} / \mathrm{L}$ (D1) and $1 \mathrm{mg} / \mathrm{L}$ (D2) possessed the highest percentage of callus growth compared to 2,4 D $0 \mathrm{mg} / \mathrm{L}$ (D0). Generally, explants will have different reactions towards their developments on each observation. The results are presented in Figure 1.
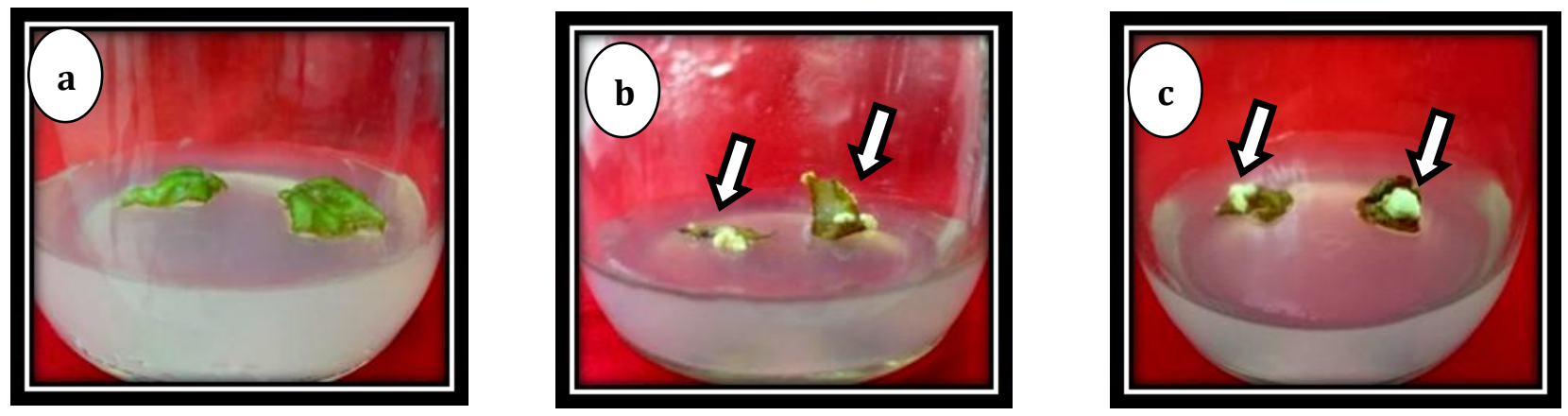

Figure 1. The growth of durian leaf explants. Initiated explants (a); Callus appeared on explants (b); explants with developing a callus on them (c).

Figure 1a shows a planted explant. This explant did not show signs of growth at the earlier observation. Figure $1 \mathrm{~b}$ shows induced callus explant. Generally, explants induced callus at 4-7 weeks after application. Figure 1c shows an explant at the end of observation, which had bigger callus and its color dried on the leaf tip. Most of the leaf explants appeared to be swollen at first before forming the callus.

The growth of callus on explants is one of the indicators of a successful application in the plant culture. The callus is a growing mass of unorganized cells (Indah dan Ermavitalini, 2013). Callus goes through 3 (three) stages in its development - induction, cell division and differentiation (Zulkarnain dan Lizawati, 2011). Growing callus needs growth regulators such as auxin to induce the callus. Auxin is a plant growth regulator that contributes to the development of plant cells, phototropism, geotropism, apical dominance, root growth, parthenocarpy, abscission, callus formation, and respiration. 2,4-D (2,4-Dichlorophenoxyacetic Acid) is an auxin often used to stimulate the formation of callus. The application of 2,4 $\mathrm{D}$ affects the growth of callus (percentage of callus growth). Auxin increases cell growth, cell division, and development of adventive roots. Auxin is needed in culture media to improve somatic embryogenesis on cell suspension cultures. A high concentration of auxin will stimulate callus formation and suppress morphogenesis (Marlin, et al., 2012).

The results revealed that the application of kinetin and 2,4 $\mathrm{D}$ both alone and the combination did not differ significantly in the callus growth period. The results are given in Table 2.

Table 2. Time length of callus growth on durian leaf explants treated with kinetin and 2,4 D in vitro

\begin{tabular}{lc}
\hline \multicolumn{1}{c}{ Treatments } & Callus growth period (DAP) \\
\hline Concentrations of Kinetin (K) : & $26.96(5.09 \mathrm{a})$ \\
$0 \mathrm{mg} / \mathrm{L}(\mathrm{K} 0)$ & $34.41(5.86 \mathrm{a})$ \\
$0.1 \mathrm{mg} / \mathrm{L}(\mathrm{K} 1)$ & $29.86(5.43 \mathrm{a})$ \\
$0.5 \mathrm{mg} / \mathrm{L}(\mathrm{K} 2)$ & \\
\hline Concentrations of 2,4-D (D) : & $30.66(5.52 \mathrm{a})$ \\
$0 \mathrm{mg} / \mathrm{L}(\mathrm{D} 0)$ & $27.67(5.23 \mathrm{a})$ \\
$0.5 \mathrm{mg} / \mathrm{L}(\mathrm{D} 1)$ & $32.73(5.63 \mathrm{a})$ \\
$1 \mathrm{mg} / \mathrm{L}$ (D2) & \\
\hline Mean values followed by the same letters in the same columns did not differ significantly, as determined by DMRT at probability level \\
$5 \%$. Values in parenthesis were results of transformation using formula $\sqrt[2]{(x+0,5),} \quad$ DAP = Days After Planting
\end{tabular}

Table 2 illustrates that the application of growth regulator kinetin did not affect the callus growth period. 
Also, the application of $2.4 \mathrm{D}$ did not influence the period of callus growth. Time length for callus to grow on leaf explants of durian depends on the explants. Each explant has a different reaction when absorbing nutrients, and also it depends on how much growth regulator given to explant. This statement is in line with Mandang (2013) in Mayasari (2017) that the application of growth regulators in a small amount can help or inhibit the growth of explants.

The results of the $F$ test revealed that concentrations of kinetin and 2,4 D had improved callus development. The results of DMRT at probability $5 \%$ can be seen in Table 3 .

Table 3. Percentage of callus development on durian leaf explants treated with kinetin and 2,4 D in vitro.

\begin{tabular}{|c|c|c|c|c|c|c|}
\hline \multirow{2}{*}{\multicolumn{2}{|c|}{ Treatments }} & \multicolumn{5}{|c|}{ Percentage of callus development (\%) } \\
\hline & & 3 WAP & 4 WAP & 5 WAP & 6 WAP & 7 WAP \\
\hline $\begin{array}{l}\text { Concentrations of } \\
0 \mathrm{mg} / \mathrm{L}(\mathrm{K} 0)\end{array}$ & Kinetin $(\mathrm{K})$ : & $2(0.72 a)$ & $3(073 a)$ & $6(0.75 a)$ & $9(0.76 a)$ & $12(0.78 a)$ \\
\hline $0.1 \mathrm{mg} / \mathrm{L}(\mathrm{K} 1)$ & & $0(0.70 \mathrm{~b})$ & $0(0.70 \mathrm{~b})$ & $1(0.71 \mathrm{~b})$ & $3(0.73 \mathrm{~b})$ & $8(0.76 \mathrm{~b})$ \\
\hline $0.5 \mathrm{mg} / \mathrm{L}(\mathrm{K} 2)$ & & $0(0.70 \mathrm{~b})$ & $0(0.71 \mathrm{~b})$ & $3(0.73 \mathrm{ab})$ & $8(0.76 \mathrm{ab})$ & $13(0.79 a)$ \\
\hline $\begin{array}{l}\text { Concentrations of } \\
0 \mathrm{mg} / \mathrm{L}(\mathrm{D} 0)\end{array}$ & 2,4-D (D) : & $0(0.70 a)$ & $0(0.70 a)$ & $0(0.70 \mathrm{a})$ & $0(0.70 \mathrm{~b})$ & $0(0.70 \mathrm{~b})$ \\
\hline $0,5 \mathrm{mg} / \mathrm{L}(\mathrm{D} 1)$ & & $1(0.71 a)$ & $1(0.72 a)$ & $5(0.74 a)$ & $10(0.77 \mathrm{a})$ & $16(0.81 a)$ \\
\hline $1 \mathrm{mg} / \mathrm{L}(\mathrm{D} 2)$ & & $1(0.71 a)$ & $2(0.72 a)$ & $4(0.73 \mathrm{ab})$ & $7(0.75 a)$ & $11(0.78 a)$ \\
\hline
\end{tabular}

Mean values followed by the same letters in the same columns did not differ significantly, as determined by DMRT at probability level $5 \%$. Values in parenthesis were results of transformation using formula $\sqrt[2]{(x+0,5)}$, WAP $=$ Weeks After Planting

Table 3 shows that the application of kinetin has generated callus development. The application of kinetin $0.5 \mathrm{mg} / \mathrm{L}(\mathrm{K} 2)$ demonstrated a higher percentage of callus development compared to other treatments. The application of kinetin $0.5 \mathrm{mg} / \mathrm{L}$ in this research gave higher callus growth compared to different concentrations. The application of kinetin in a culture media promotes callus growth. Also, the application of cytokinin plays an important role in stimulating the growth and development of explants. Limited amounts given to a culture media could inhibit the cell division of cultured tissue (Zulkarnain, 2009).

The application of 2,4 $\mathrm{D}$ affected the development of callus. The concentration of $0.5 \mathrm{mg} / \mathrm{L}$ of $2.4 \mathrm{D}$ (D1) contributed better callus growth compared to other concentrations. It indicated that the application of 0.5 $\mathrm{mg} / \mathrm{L}$ (D1) had induced callus on durian leaf explants, while the lowest concentration of 2,4 D (D1) demonstrated the lowest result.

This result corroborates with a statement that application of auxin to an MS media has induced callus growth on durian leaf explants (Sugiyarto dan Kuswandi, 2013). A high concentration of auxin is needed to stimulate callus formation (Marlin et al., 2012). This high concentration of auxin will stimulate callus formation and inhibit morphogenesis. It also increases the activity of auxin helping the explants to induce callus in this research. The color of the callus will generally change if specific reactions occur. Reactions that can cause callus discoloration, for example, the loss of chlorophyll compounds from the callus that causes the color of the callus to turn greenish-white or other colors. The colors of the callus are shown in Figure 3.
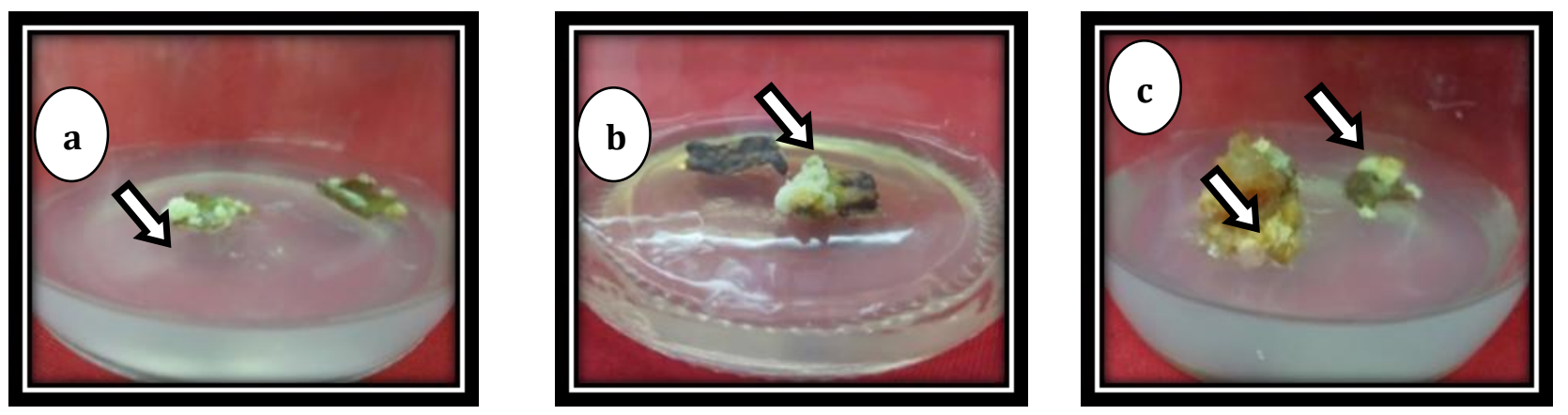

Figure 3. Callus colors. White (a); cream (b); brown and green yellowish (c).

Figure 3 reveals that each explant has induced callus with different colors and shapes. These differences are influenced by active compounds contained in the explants or media.

Call us growth on durian leaf explants started in white color. However, this color of callus changed with time, associated with several reactions occurred in explants or planting media of explants. The color changes were classified into the following categories: white, milky white, brown and green yellowish. These categories of color indicated that each treatment demonstrated different responses shown in different 
colors.

The color of the callus is dominated by white, which indicates that the callus is an embryonic tissue that does not yet contain chlorophyll, but has starch content in the form of stored polysaccharides in plants (Muliati et al, 2017; Ariati et al., 2012). Greenish white callus was probably the brightest callus with a lesser amount of chlorophyll compounds (Widyawati, 2010).

The green color in callus is linked to cytokinin activity in chlorophyll formation (Rahayu dan Mardini, 2015). Callus color indicates the availability of chlorophyll compound in plants. The formation of green callus indicating the presence of chlorophyll in high amounts (Fatmawati, 2008). The changes in callus color from yellow to greenish-yellow, followed by the formation of spots or green nodules are the signs of shoot formation (Lestari dan Yunita, 2008). If callus color turns into brown or dark colour, it indicates that callus has a problem called browning callus, which caused by accumulation and and oxidation of phenolic compound formed in explants or callus. Callus browning suppressed explant growth and inhibited callus formation.

In this research, not all explants has grown well, some of them has turned into yellow color and eventually died due to inappropriate selection of type of explants, concentration of growth regulators and improper balance of disinfectant used in sterilization stage. It influenced the success of callus formation. (Santoso dan Fatimah, 2014). Therefore, explants will have difficulties in inducing callus if there is unbalanced application of growth regulators. Explants will not be able to grow and die.

\section{CONCLUSION}

The application of kinetin has influenced the callus induction on durian leaf explants in vitro. The application of kinetin $0.5 \mathrm{mg} / \mathrm{L}$ (K2) demonstrated the best effect compared to other concentrations. The application of 2,4-D also gave a positive impact to callus induction on durian leaf explants through in vitro bioassay. The provision of 2,4-D $0.5 \mathrm{mg} / \mathrm{L}$ (D1) revealed the best concentration compared to others. There was no interaction between kinetin and 2,4-D applications to the callus growth on durian leaf explants in vitro in all variables observed.

\section{ACKNOWLEDGMENT}

The writers thank the Ministry of Research, Technology, and Higher Education for funding this research through Applied Research Program with contract No: 02/UN45.11/PT/III/2019 dated 19 March.

\section{REFERENCES}

Anjani, N. P., (2011). Sterilization techniques and growth response of floral stalk explants of orchid Phaleonopsis sp. treated with growth regulator 2i-p in vitro (written in Indonesian language). Script. Program Sarjana, Universitas Udayana Denpasar, Indonesia.

Ariati, S. N., Muslimin, Waeniati, Suwastika dan Nengah. (2012). Induction of cocoa (Theobroma cacao L.) on MS medium treated with 2,4-D, BAP and coconut water (written in Indonesian language). Jurnal Natural Science, 1(1).74-84.

Chugh, S., Satyakam, G and I. Usha. R. (2009). Micropropagation of orchids: A review on the potential of different explants. Scientia Horticulturae, 122 (4): 507-520.

Daud, N. H., Jayaraman, S., dan Mohamed, R. (2012). Methods Paper: An Improved Surface Sterilization Technique for Introducing Leaf, Nodal and Seed Explants of Aquilaria Malaccensis from Field Sources Into Tissue Culture. Aspac J. Mol Biol Biotechnol 20. 55-58.

[Deptan] Departemen Pertanian. (2012). Pertanian. http://hortikultura.deptan.go. id/? q=node/327. [12 Maret 2013].

Fatmawati, A. 2008. Study of Concentrations of BAP and 2,4-D on Callus Induction of Artemisia annua L. In Vitro (written in Indonesian language). Script. Fakultas Pertanian UNS. Surakarta.

Feng, J., Wang, Y., Yi, X., Yang, W., and HAE, X. (2016). Phenolics from Durian Exert Pronounced NO Inhibitory and Antioxidant Activities. Journal of Agricultural and Food Chemistry. 64 (21). 4273-4279.

Handayani, RS., Poerwanto, R., Sobir, Purwito, A., Ermayanti, TM. (2013). Effect of rootstock and types of shoots on micrografting in mangosteen in vitro (written in Indonesian language). J. Agron. Indonesia. 41 (1) : 47-53

Handayani, RS., Ismadi, Sayuti, M., Hasyim, CR. (2018). Effect of sterilant ethanol and mercuric chloride on the growth of durian (Durio zibethinus Murr.) shoot explants in vitro (written in Indonesian language). Prosiding Forum Komunikasi Perguruan Tinggi Pertanian Indonesia (FKPTPI) Banda Aceh: 271-276.

Indah, N. P., dan Ermavitalini, D. (2013). Callus induction of tamanu (Calophyllum inophyllum Linn.) leaves with combination of concentrations of 6-Benzylanimopurine (BAP) and 2,4-Dicholoropeoxyacetic Acid (2,4-D) (written in Indonesian language). Jurnal Sains dan Seni Pomits, 2 (1). 2337-3520.

Lestari, E. G., dan Yunita, R. (2008). Propagation of Artemisia annua L. in vitro. (written in Indonesian language). Jurnal Agrobiogen, 4 (1). 41- 44.

Marlin, Yulian, dan Hermansyah. (2012). Initiation of embryogenic callus on cultured banana bud in Curup with application of sucrose, BAP and 2,4 D (written in Indonesian language). J., Agrivor 11(2). 275-283.

Mekonnen T, Diro M, Sharma M. (2013). Analternative safer and cost effective surface sterilization method for sugarcane (Saccharum officinarum L.) explants. Afr J Biol, 1(1), 28-32.

Muliati, T. Nurhidayah, dan Nurbaiti. (2017). Effect of NAA, BAP and their combinations on MS media to the development of Sansevieria macrophylla explants in vitro (written in Indonesian language). JOM FAPERTA, 4 (1). 1-13.

Rahayu, T. dan U. Mardini. (2015). Response of nodal and leaf explants of Madeira-vine (Anredera cordifolia L.) on MS media with varied concentrations of BAP (written in Indonesian language). Seminar Nasional XII Pendidikan Biologi FKIP UNS. Surakarta: Universitas Negeri Surakarta.

Riyadi, I., dan Tirtoboma. (2004). Effect of application of on somatic embryogenesis induction of Arabica coffee (written in Indonesian language). Balai Penelitian Bioteknologi Perkebunan Indonesia. Buletin Plasma Nutfah. Bogor. 10 (2). 82-89.

Santoso, U., dan Fatimah. (2014). Kultur Jaringan Tanaman. Malang : UMM Press. 
Sitinjak, M. A., Isda, M. N., dan Fatonah, S. (2015). Callus induction of rodent tuber (Typhonium sp.) leaf explants associated with application of 2,4-D and Kinetin (written in Indonesian language). Jurnal Biologi, 8 (1).38.

Sugiono, C., dan Hasbianto, A. (2014). The development of tissue culture technique application on potato plants (Solanum tuberosum L.) (written in Indonesian language) In Prosiding Seminar Nasional “ Inovasi Teknologi Pertanian Spesifik Lokasi" Banjarbaru 6-7 Agusutus 2014. (Pp 435-443).

Sugiyarto, L., dan P. C. Kuswandi. (2013). Exploration of sterilization method and types of media for durian (Durio zibethinus, L.) propagation in vitro (written in Indonesian language). J. Sains Dasar. 2(1). 20-24.

Teguh, S. M. (2017). Effect of growth regulators 2,4-D (Dichlorophen-oxyacetid Acid) and kinetin to callus induction of cinnamon (Cinnamomun burmanii) leaf explants (written in Indonesian language). Jambi. Universitas Jambi.

Widyawati, G. (2010). Effect of Several Concentrations of NAA and BAP to callus induction of bubble bush (Jatropha curcas). Thesis. Surakarta. Universitas Sebelas Maret.

Yunus, A., Samanhudi., A.T. Sakya dan M. Rahayu. (2010). Teknologi Kultur Jaringan. Surakarta: UNS Press.

Zulkarnain dan Lizawati. (2011). Callus proliferation of hypocotyl and cotyledon explants of bubble bush (Jatropha curcas L.) treated with 2,4-D (written in Indonesian language). Jurnal Natural Indonesia, 14 (1). 19-25.

Zulkarnain, H. (2009). Kultur Jaringan Tanaman. Bumi Aksara. Jakarta. 
